11. Carosio F., Alongi J. Ultra-Fast Layer-by-Layer Approach for Depositing Flame Retardant Coatings on Flexible PU Foams within Seconds // ACS Applied Materials \& Interfaces. 2016. Vol. 8, Issue 10. P. 6315-6319. doi: 10.1021/acsami.6b00598

12. Samarskiy A. A., Vabishchevich V. P. Vychislitel'naya teploperedacha. Moscow: Editorial URSS, 2003. 784 p.

13. Bahvalov N. S., Zhidkov N. P., Kobel'kov G. M. Chislennye metody: ucheb. pos. Moscow: Nauka, 1987. 600 p.

14. Umnyakova N. P. Kak sdelat' dom teplym: sprav. pos. Moscow: Stroyizdat, 1996. 368 p.

\begin{abstract}
Досліджено вплив на довкілля параметрів спалювання газу при роботі газоперекачувального агрегату компресорної станиіі. Встановлено ступінь зменшення реального впливу викидів на довкілля у місиях розташування компресорних станцій залежно від величини коефіцієнта надлишку повітря. Запропоновано рекомендаціi, конструктивні та технологічні вдосконалення для підвищення рівня екологічної безпеки на об'єктах транспортування нафтогазового комплексу

Ключові слова: екологічна безпе$\kappa а$, газоперекачувальний агрегат, забруднення довкілля, атмосфера, нафтогазовий комплекс
\end{abstract}

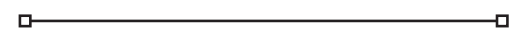

Исследовано влияние на окружающую среду параметров сжигания газа при работе газоперекачивающего агрегата компрессорной станиии. Установлена степень уменьшения реального влияния выбросов на окружаюшую среду в местах расположения компрессорных станиий в зависимости от величины коэффициента избытка воздуха. Предложены рекомендачии, конструктивные и технологические усовершенствования для повышения уровня экологической безопасности на объектах транспортировки нефтегазового комплекса

Ключевые слова: әкологическая безопасность, газоперекачивающий агрегат, загрязнение окружающей среды, атмосфера, нефтегазовый комплекс

\section{ESTABLISHING THE DEPENDENCE OF POLLUTANT CONCENTRATION ON OPERATIONAL CONDITIONS AT FACILITIES OF AN OIL- AND-GAS COMPLEX}

T. Yats ysh y n $\mathrm{PhD}$, Associate Professor* E-mail: yatsyshyn.t@gmail.com

Yu . Mykhailiuk

$\mathrm{PhD}$, Associate Professor* E-mail: Julja-Mihayyljuk@rambler.ru

M. Li a k h

PhD, Professor Department of Oil and Gas Equipment**

E-mail:mm.lyakh@gmail.com

I. Mykhailiuk

$\mathrm{PhD}$, Associate Professor

Departmen of informatics** E-mail: irinamuhajluk@gmail.com

V. S a v y k

$\mathrm{PhD}$, Associate Professor Department of the equipment of oil and gas fields Poltava National Technical Yuri Kondratyuk University Pershotravnevyi ave., 24, Poltava, Ukraine, 36011

E-mail: savicppntu@rambler.ru

I. Dobrovols k y Chief Mechanic

PJSC "Ukrgazvydobutok"

Sumska str., 43b, Kharkiv, Ukraine, 61058

E-mail: igor.dobrovolskyi@gmail.com

*Department of ecology**

**Ivano-Frankivsk National Technical University of Oil and Gas Karpatska str., 15, Ivano-Frankivsk, Ukraine, 76019

\section{Introduction}

Since the very beginning of its existence, the oil-and-gas industry has had an extremely large negative impact on the environment (soils, geological environment, water resources, atmospheric air). Present-day technologies ensure reduction of the magnitude of anthropogenic impact but this problem still remains unresolved.

Each stage of the life cycle of the oil-and-gas industry facilities is polluting and bringing about high risks of creating irreversible ecologically dangerous consequences for all environment components. 
For example, a study was carried out at the IvanoFrankivsk National Technical University of Oil and Gas aimed at raising the level of environmental safety of oil and gas production facilities. The study was based on elucidation of the regularities of influence of design and operational characteristics of the drilling rig equipment on environmental state of the near-earth atmosphere layer (NEAL). Theoretical, experimental, and field studies were carried out which enabled determination of the main pollutant sources. A method forpredicting propagation of air pollution and a design of individual elements of the drilling rig equipment have been proposed to reduce NEAL pollution [1-3].

The next study stage is the gas transportation system of Ukraine, in particular, gas blowers (GB) of compressor stations that are the subject of these studies.

Emissions from combustion of natural gas by gas turbine drives of the compressor station GB on gas pipelines and underground gas storage facilities make up about $16 \%$ of total emissions of the industry, or $22 \%$ of the gas transportation activities [4]. About $50 \%$ of GB are morally and physically obsolete and have unsatisfactory ecological characteristics as forthe level of concentration of harmful substances in their own emissions [5].

Large amounts of gaseous substances, especially greenhouse gases and gases contributing to acid rainfalls enter the atmosphere. It is necessary to note specifics of pollution of the near-earth layer of atmosphere where migration is rapid (depending on concrete natural factors) and a direct negative impact on the environment components occurs in a short time.

It is important that pollution of the near-earth layer of atmosphere occurs not only in emergencies. Technological processes and equipment of the gas transportation facilities pollute environment at all stages of their life cycle. Harmful substances (nitrogen oxides $\mathrm{NO}_{\mathrm{x}}$, carbon monoxide $\mathrm{CO}$, non-methane volatile organic compounds), in particular, greenhouse gases (carbon dioxide $\mathrm{CO}_{2}$, methane $\mathrm{CH}_{4}$, nitrous oxide $\mathrm{N}_{2} \mathrm{O}$ ) are discharged into environment.

The problem can only be solved by revealing shortcomings and developing and substantiation of the methods for their elimination. The presented studies are aimed at improvement of the environmental safety of GB.

\section{Literature review and problem statement}

It was resolved by Directive 2008/50/EC of the European Parliament and Council [6] that pollution of environment to the levels minimizing harmful effects on human health should be reduced with a strong focus on vulnerable groups of population and the environment in general. As stated in the Directive, it is especially important to combat pollutant emissions directly in their sources, identify and implement the most effective measures to reduce air pollution at the local level. Information on pollution, effects of the harmful substances entering the environment and the methods for their reduction or elimination must be available to all.

Fig. 1 shows a diagram constructed using the results obtained by I.Ch. Leshchenko [4] in which main gas industry process steps and the volumes of emissions occurring inordinary operation conditions are highlighted. One of the greatestgaseous emissionsoccurs at the stage of transportation. It is accentuated that GBs are the source of greenhouse gas emissions emitting thousands of tons of pollutants a year.
The analyzed data require a significant refinement regarding emission ratiosat all stages of the gas industry activity.

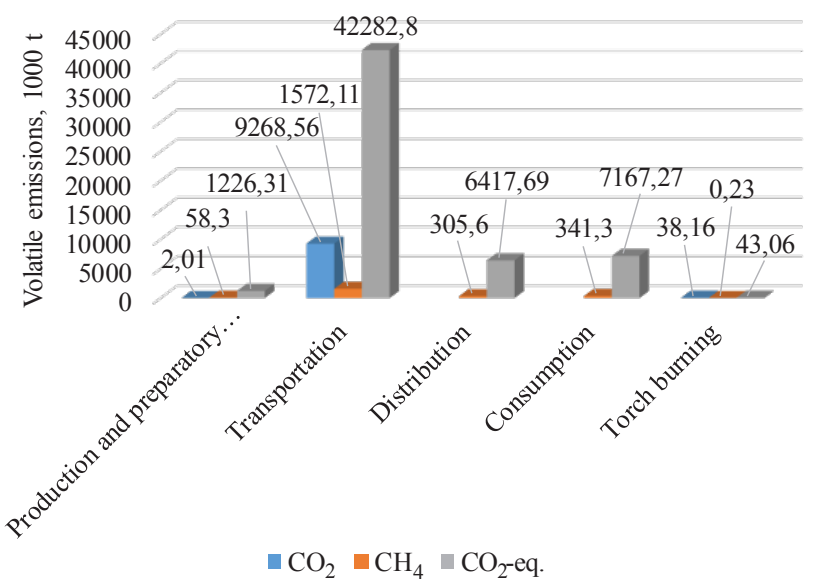

Fig. 1. Distribution of greenhouse gas emissions among the stages of the gas industry according to the calculations presented in [4]

Fuel combustion is the main source of nitrogen oxide and nitrogen dioxide in atmosphere. Nitrogen dioxide dominates often in comparison with other pollutants. In determining permissible concentrations of nitrogen oxides, one must take into account not only the impact on the human body and environment but also on worsening visibility and photochemical reactions in atmosphere [7].

When fuel and air mixture is burnt in boilers, nitric oxide $\mathrm{NO}$ is formed. It is more thermodynamically stable at high temperatures than higher nitrogen oxides. On leavingthe chimney and mixing with air, $30-35 \%$ of NO turn into $\mathrm{NO}_{2}$ in 30 seconds. Therefore, it is believed that up to $80 \%$ of nitrogen oxides in atmospheric air are mostly $\mathrm{NO}_{2}$. Toxicity of $\mathrm{NO}_{2}$ manifests itselfby irritating effects on mucous membrane of eyes and respiratory tract, reduction of oxygen supply of the organism, disturbance of respiratory functions and activity of the central nervous system. Penetrating the lungs, NO gas causes their damage and swelling [8].

It was established that under the action of solar radiation, nitrogen dioxide is decomposed into nitrogen oxide and oxygen. This reaction results in a greater number of secondary functions, emergence of active radicals and ozone. In presence of a hydrocarbon background, nitric oxides initiate formation of substances with a strong toxic effect:peroxydacetyl nitrate (PAN) and peroxydenbenzyl nitrate (PBN) of ozone. As a result of combined action of nitrogen oxides, ozone and substances of the PAN type, toxicity of their mixture increases by more than an order of magnitude compared with toxicity of individual components. In addition, $\mathrm{NO}_{2}$ gas has carcinogenic properties which make it especially dangerous for humans [9]. As a result of emission of pollutants formed during combustion of natural gas, geoecological risks aggravate. Photochemical and physical-chemical transformations that occur in atmosphere contribute to the penetration of pollutants in the surface and aquatic ecosystems of the compressor station zone of influence [10]. Therefore, reduction of $\mathrm{NO}_{2}$ emissions and methods for extracting them from atmosphere is the issue of high importance.

When fuels are burnt, carbon oxides account for about half of the total amount of all harmful substances entering the atmosphere. Carbon oxide is a highly toxic substance 
and such smallvolume concentrationsas $0.01-0.02 \%$ CO in the inhaled air cause poisoning and a concentration of $0.2 \%\left(2.4 \mathrm{mg} / \mathrm{m}^{3}\right)$ invokes dizziness in 30 minutes. Carbon oxide reacts with the blood pigment, hemoglobin, forming carboxyhemoglobin [11].

The ecological problem ata compressor station (CS) location is also exacerbated by the fact that harmful substances such as carbon dioxide, carbon monoxide, nitric oxide can remain in atmosphere for a long time (for several years) [12]. Analysisof available scientific works shows relevance of the studies aimed at reduction of nitrogen dioxide and carbon monoxide emissions in GB operation.

Various methods and technological solutions for estimation, forecasting and reduction of harmful emissions in GB operation were developed among which works [5, 13-15] areworth noting. Study [5] shows low efficiency of the operated GB and unsatisfactory environmental characteristics (level of noise, toxicity of exhaust gases). The author proposes a basic scheme for obtaining carbonic acid using secondary resources of gas pipeline compressor stations but introduction of this technology requires construction of an additional process line.

Also known is a method of cleaning boiler plant exhaust gases from carbon monoxide and a device for its implementation [13]. Its disadvantage is that cleaning is incomplete as not all the mass of gas contacts surface when going through tubes.Besides, the system of tubes creates additional resistance to the gas exit and the equipment is large sized.

In [14], a model is proposed as a function of multiple regression which establishes relationship between emission of polluting gases $N O_{x}$, the cost $Q_{F G}$ of fuel gas and the excess air coefficient $\lambda$ :

$$
N O_{x}=-754,3357+67,7218 \lambda+0,0088 Q_{F G} .
$$

The constructed three-dimensional model makes it possible to accurately determine amount of nitrogen oxide emissions if gas consumption and the excess air coefficient are known. Also,quantitative assessment is only possible using the data recorded by an automatic system of thermalunit control. Models of determination of other toxic components are not proposed in these studies.

There is a procedure of parametric identification of the actual equipment characteristics which allows one to determine reliable values of the main values and performance relating to reliability, economic efficiency and environment-friendly operation andensures implementation of a comprehensive systems analysis of the actual state of equipment, continuous monitoring of parameters and forecasting [15]. However, it is necessary to conduct a series of experimental studies to determine optimum performance characteristics of the equipment for an effective functioning of the proposed methodology. The analyzed information sources state the need to reduce harmful emissions from GB. The proposed solutions require revision at a level of real tests and determination of environmentally safe modes of GB operation. Therefore, it is necessary to determine indicators and establish dependencies that will make it possible to increase the level of environmental safety of the studied facilities.

Improvement of ecological safety of the oil-and-gas industry requires application of a variety of approaches including studies of the impact of industrial facilities on all environment components and the impact of each facility, in particular on the environment components. There is anacute need to reduce technogenic pressure on environment by improving technological processes and equipment. Therefore, study of the parameters of gas combustion at gaspumping units and their environmental impact will enable optimization ofGB operation and technical solutions to improve environmental safety of the gas transportation facilities.

\section{The aim and objectives of the study}

The main objective of this work is raising the level of environmental safety of the oil and gas facilities, for example, gaspumping units of compressor stations by establishing dependence of pollutant concentration on the operating conditions.

The following tasks were set to achieve thisobjective:

- todetermine dependence of pollutant concentrations on the GB technological parameters;

- tosimulate emissions of harmful substances at specified technological and natural factors;

- toestablish dimensions of the adjusted sanitary protection area at the zone of the compressor station influence;

- todetermine rational conditions and parameters of operation of the gas pumping unit;

- topropose methods for raising the level of ecological safety of the studied facility.

\section{Studying the environmental impact of the gas burning parameters of gaspumping units}

\subsection{The study procedure}

The study was carried out on the GB of GTK-10I compressor station of the Bogorodchansk linear-production directorate of main gas pipelines. Concentrations of oxides of nitrogen and carbon in emissions were determined using Testo-350 gas analyzer. Depending on the operating conditions, technological factors varied in the following limits: $6,034-8,649 \mathrm{~kW}$ for electric power, $550-770.2{ }^{\circ} \mathrm{C}$ for combustion temperature, 1-1.62 for air excess coefficient, $1,390-3,187 \mathrm{~m}^{3}$ /year for gas consumption.

Calculation of pollutant dispersion was made using 5.23 version of Eol-Plus software complex.

Initial data for calculating the near-earth concentrationsof pollutants were as follows:

- parameters of emission sources;

- climatological characteristics;

- near-earth background concentrations of harmful substances.

To calculate atmospheric pollution, the XOY rectangular coordinate system with origin $\mathrm{O}$ coincidentwith the emission source was taken. To calculate the near-earth pollutant concentrations, a 5,000 $\times 5,000 \mathrm{~m}$ size rectangle was taken in the first quadrant of the coordinate axes with a $250 \mathrm{~m}$ grid pattern.

Climatic parameters for the calculation are shown in Table 1

Pollution of the near-earth air layer was estimated according to the highest calculated value of the near-earth concentration at the boundary of the sanitary protection zone (SPZ) in the period of adverse weather conditions for all pollutants. The average annual wind rose for this areawas as follows: 10.7 to the north; 9.7 to the northeast; 16.0 to the east; 9.4 to the south-east; 11.8 to the south; 12.1 to the south-west; 16.9 to the west; 13.4 to the south-west. 
Table 1

Climatic characteristics and coefficients determining conditions of pollutant dispersion

\begin{tabular}{|c|c|c|}
\hline $\begin{array}{c}\text { Item } \\
\text { No. }\end{array}$ & Indicator name & Value \\
\hline 1 & $\begin{array}{c}\text { Coefficient "A" corresponding to meteorological } \\
\text { conditions at which pollutant concentration in air } \\
\text { is maximal }\end{array}$ & 200 \\
\hline 2 & $\begin{array}{c}\text { Average outdoor temperature of the warmest } \\
\text { month, }{ }^{\circ} \mathrm{C}\end{array}$ & +24.3 \\
\hline 3 & ${\text { Average outdoor temperature of the coldest month, }{ }^{\circ} \mathrm{C}}^{-}$ & -4.2 \\
\hline 4 & Coefficient of land relief impact $^{-}$ & 1 \\
\hline 5 & $\begin{array}{c}\text { Wind velocity (average long-term data) exceeded at } \\
\text { a repeating rate bymore than } 5 \%, \mathrm{~m} / \mathrm{s}\end{array}$ & $10-11$ \\
\hline 6 & Maximum wind velocity registered, $\mathrm{m} / \mathrm{s}$ & 28 \\
\hline
\end{tabular}

4. 2. Determination of the dependence of pollutant concentrations on the GB parameters

The main substances emitted into atmosphere during combustion of gas at the GB are products of complete gas combustion, i.e.oxides of nitrogen and carbon, and the substances formed in high-temperature processes and chemical reactions.

Various toxicity levels of the combustion products have been measured. They varied within the limits of $32.2-$ $68.5 \mathrm{mg} / \mathrm{m}^{3}$ for nitric oxide, $\mathrm{NO} ; 16.2-43 \mathrm{mg} / \mathrm{m}^{3}$ for nitrogen dioxide, $\mathrm{NO}_{2} ; 70.4-480 \mathrm{mg} / \mathrm{m}^{3}$ forcarbon monoxide, $\mathrm{CO}$.

The measured values of the exhaust gas concentrations (nitrogen oxides, $\mathrm{NO}_{\mathrm{x}}$ and carbon monoxide, $\mathrm{CO}$ ) were analyzed depending on the gas consumption rate $\mathrm{Q}$, the air excess coefficient, nominal power and combustion temperature [16]. Single-factor regression equations have been derived from the obtained paired associations to elucidate influence of above factors on the concentration of exhaust combustion products. According to the analysis of the experimental data and the paired regression analysis, it was found that the excess air coefficient $\alpha$ had the greatest influence on the following exhaust gas concentrations: $\mathrm{C}_{\mathrm{NO}}, \mathrm{C}_{\mathrm{NO} 2}$ and $\mathrm{C}_{\mathrm{CO}}$. The equations of the paired regression of concentration of nitrogen oxides and carbon monoxide on the excess air coefficient are given in Table 2.

Table 2

Equations of the paired regression of concentration of nitric oxide, NO, on the excess air coefficient

\begin{tabular}{|c|c|c|}
\hline Regression equation & $\begin{array}{c}\text { Number of } \\
\text { observations }\end{array}$ & $\begin{array}{c}\text { Correlation } \\
\text { coefficient }\end{array}$ \\
\hline $\mathrm{C}_{\mathrm{NO}}=47.229 \alpha-8.608$ & 52 & 0.789895 \\
\hline $\mathrm{C}_{\mathrm{NO} 2}=28.019 \alpha-7.104$ & 52 & 0.669387 \\
\hline $\mathrm{C}_{\mathrm{CO}}=-398.76 \alpha+719.56$ & 52 & 0.70798 \\
\hline
\end{tabular}

It was established that as for the absolute growth, the excess air coefficient had the greatest influence on the growth of concentration of nitrogen oxides and carbon monoxide. With its increase by $1 \%, \mathrm{C}_{\mathrm{NO}}$ increased by $1.02 \%, \mathrm{C}_{\mathrm{NO} 2}$ increased by $0.96 \%$, and $\mathrm{C}_{\mathrm{CO}}$ decreased by $2.34073 \%$.

To determine parameters of achieving minimum values of pollutant concentrations in the GB emissions, dependence of the emission concentrations on the excess air coefficient (Fig. 2) was established. Since concentrations of substances acquire values of different order, the dependence was constructed in the coordinates of the conditional values $b$ which were determined by dividing each value by the largest value in the series.

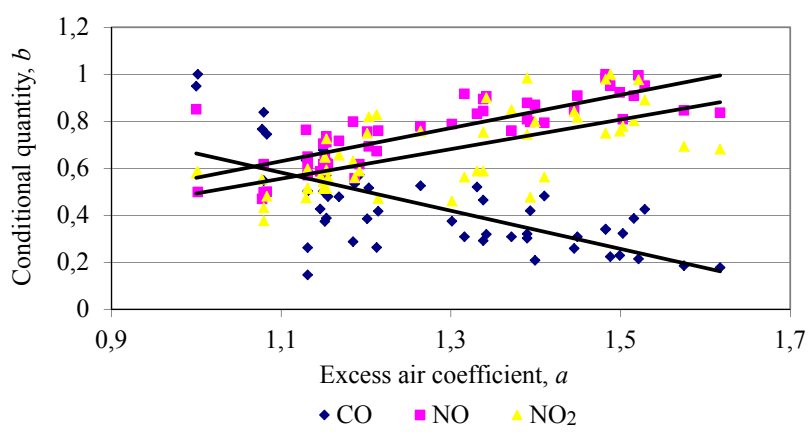

Fig. 2. Dependence of concentrations of pollutant emissions on the excess air coefficient, $\alpha$

In this connection, a necessary arises to establish the degree of reduction of the real environmental impact of emissions in the locations of compressor stations depending on the magnitude of the excess air coefficient.

4. 2. Simulatingthe emissions of harmful substances under various technological parameters of the GB operation

Using the Eol-Plus, v. 5.23 software package,the $\mathrm{NO}_{2}$, $\mathrm{NO}, \mathrm{CO}$ dispersion zone was simulated at excess air coefficients $\alpha$ of $1.0 ; 1.1 ; 1.3 ; 1.6$.Fig. 3 shows simulation of nitrogen dioxide dispersion for an excess air coefficient of 1.3.The main parameters of dispersion were as follows:

- the ratio of actual concentration to the maximum permissible concentration within the sanitary protection zone, maximum 1.16 MPC;

- the ratio of actual concentration to the maximum permissible concentration within the sanitary protection zone, minimum 0.71 MPC;

- the ratio of actual concentration to the maximum permissible concentration outside the sanitary protection zone, maximum 1.05 MPC;

- excessof the maximum permissible concentration was observed both within and outside the sanitary protection zone. Actual concentrations of nitrogen dioxide equal to the maximum permissible concentration were observed at a distance of $1,240 \mathrm{~m}$ from the pollution source. This distance exceeds the size of the normative sanitary protection zone by $240 \mathrm{~m}$.

Based on the simulation conducted for $\mathrm{NO}_{2}, \mathrm{NO}, \mathrm{CO}$ at the values of the excess air coefficient $\alpha$ equal to $1.0 ; 1.1 ; 1.3$; 1.6,pollutant concentrations within and outside the SPZ were determined (Table 3).

Table 3

Summary results of calculating the pollutant dispersion

\begin{tabular}{|c|c|c|c|c|c|}
\hline \multirow{3}{*}{$\begin{array}{c}\text { Exhaust } \\
\text { gas }\end{array}$} & \multirow{2}{*}{ Parameter } & \multicolumn{4}{|c|}{ Excess air coefficient } \\
\cline { 2 - 6 } $\mathrm{NO}_{2}$ & Within the SPZ & 0.07 & 0.93 & 1.16 & 1.41 \\
\cline { 2 - 6 } & Outside the SPZ & 0.79 & 0.85 & 1.05 & 1.27 \\
\cline { 2 - 6 } & $\begin{array}{c}\text { Distance at which no MPC } \\
\text { excess was observed, km }\end{array}$ & - & - & 1.2 & 1.6 \\
\hline \multirow{4}{*}{ NO } & Within the SPZ & 0.81 & 0.89 & 1.06 & 1.25 \\
\cline { 2 - 6 } & Outside the SPZ & 0.74 & 0.74 & 0.96 & 1.13 \\
\cline { 2 - 6 } & $\begin{array}{c}\text { Distance at which no MPC } \\
\text { excess was observed, km }\end{array}$ & - & - & 0.9 & 1.5 \\
\hline \multirow{4}{*}{$\mathrm{CO}$} & Within the SPZ & 1.13 & 0.97 & 0.86 & 0.72 \\
\cline { 2 - 6 } & Outside the SPZ & 1.08 & 0.93 & 0.83 & 0.70 \\
\cline { 2 - 6 } & $\begin{array}{c}\text { Distance at which no MPC } \\
\text { excess was observed, km }\end{array}$ & 1.6 & - & - & - \\
\hline
\end{tabular}




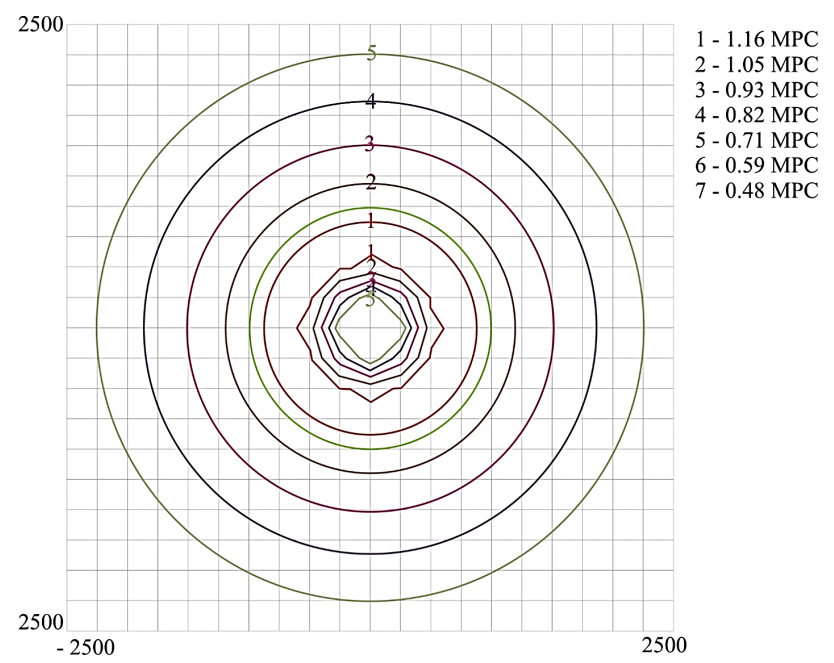

Fig. 3.Calculated data of nitrogen dioxide dispersion in the radialdirection from the emission source at the excess air coefficient $\alpha=1.3$

Fig. 4 shows dependence of the maximum values of the MPC excess order on the excess air coefficient. The data for construction of this dependence were obtained experimentally and presented for visualization of the general nature of probable dependence.

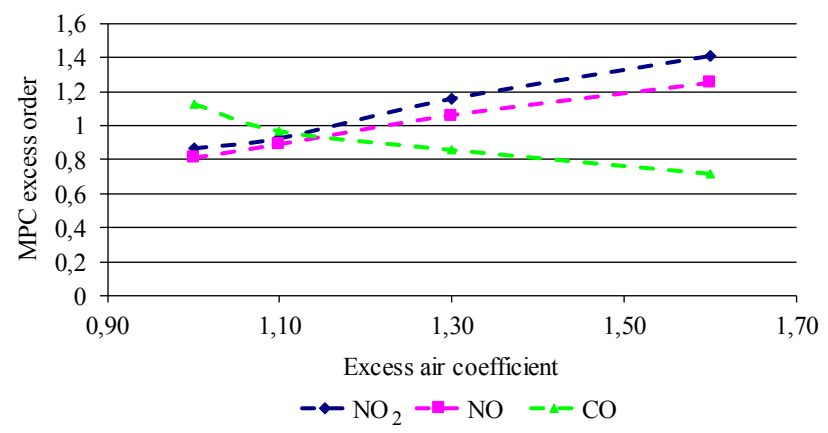

Fig. 4. Dependence of maximum values of the MPC excess order within the SPZ from the excess air coefficient, $\alpha$

With an increase in the excess air coefficient, the distance to which harmful emissions of nitrogen oxides and dioxidesspread increases. The smallest distance of emission spread was at $\alpha=1.00$ and the largest distance was at $\alpha=1.60$ (Fig. 5).

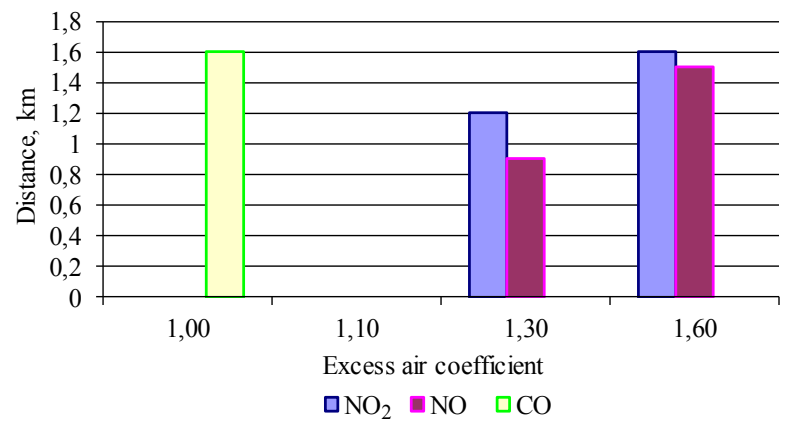

Fig. 5. Dependence of the distances of pollutant spread on the normative valuesof the excess air coefficient, $\alpha$

The simulation has allowed us to observe the MPC excess outside the existing SPZ at the values of the excess air ratio: $\alpha=1.3$ and $\alpha=1.6$ for $\mathrm{NO}_{2} ; \alpha=1.6$ for $\mathrm{NO}$ and $\alpha=1.0$ for $\mathrm{CO}$. Thus, the results show the necessity of adjusting the SPZ and establishing optimal conditions of the GB operation to raise the level of environmental safety of the area of influence of compressor stations.

4. 3. Determining the size of the adjusted sanitary protection zone of the area of the compressor station influence

In the event that concentrations of pollutants exceeding the MPC are observed in the dispersion area, adjustment of the SPZ shall be carried out taking into account the local windrose. In accordance with clause 8.6.2 of AND-86[17], the size of the sanitary protection zone was adjusted taking into account the local windrose according to formula (2):

$$
L=L_{0} \cdot \frac{P}{P_{0}}
$$

where $L$ is the calculated size of the SPZ; $L_{0}$ is the dimension of the land lot in the given direction where pollutant concentration exceeds the MPC (according to the calculations, the maximum distance from the pollution source at which actual concentration of nitrogen dioxide exceeds the MPC is $L_{0}=1,240 \mathrm{~m}$ ); $P$ is the maximum monthly average repeatability of the wind direction of the givenrhumb during the year; $P_{0}$ isrepeatability of the wind direction of one rhumb (for an 8 -rhumb windrose, $P_{0}=100 / 8=12.5 \%$ ).

Data for adjustingthe SPZ size for nitrogen dioxide at anexcess air coefficient $\alpha=1.3$ and the results of calculation of the adjusted SPZ size are presented in Table 4.

Asit can be concluded from the results of calculation, emissions of the GB equipped with a gas turbine engine of GTK-10I type, have a significant impact on the atmosphere pollution by all three substances. The degree of this effect varies depending on combustion conditions (the excess air coefficient). Fig. 6 shows a normative sanitary protection zone and its dimensions adjusted according to the windrose.

Table 4

Determination of the adjusted size of the sanitary protection zone for nitrogen dioxide at anexcess air coefficient $\alpha=1.3$

\begin{tabular}{|c|c|c|c|}
\hline \multicolumn{2}{|c|}{$\begin{array}{l}\text { Maximum average monthly repeatability of } \\
\text { wind direction in a given rhumb during a year }\end{array}$} & \multirow{2}{*}{$\frac{P}{P_{0}}$} & \multirow{2}{*}{$\begin{array}{l}\text { Adjusted } \\
\text { SPZ, } m\end{array}$} \\
\hline Direction & $\begin{array}{l}\text { Repeatability from } \\
\text { the source, } \%\end{array}$ & & \\
\hline northern & 10.7 & 0.856 & $1,061.44$ \\
\hline northeastern & 9.7 & 0.776 & 962.24 \\
\hline eastern & 16.0 & 1.28 & $1,587.2$ \\
\hline southeastern & 9.4 & 0.752 & 932.48 \\
\hline southern & 11.8 & 0.944 & 117.56 \\
\hline southwestern & 12.1 & 0.968 & $1,200.32$ \\
\hline western & 16.9 & 1.352 & $1,676.48$ \\
\hline northwestern & 13.4 & 1.072 & 1,329.28 \\
\hline
\end{tabular}

As can be seen from Fig. 6, adjusted dimensions of the sanitary protection zone at various values of the excess air coefficientmay be substantially larger than the normativedimensions. 


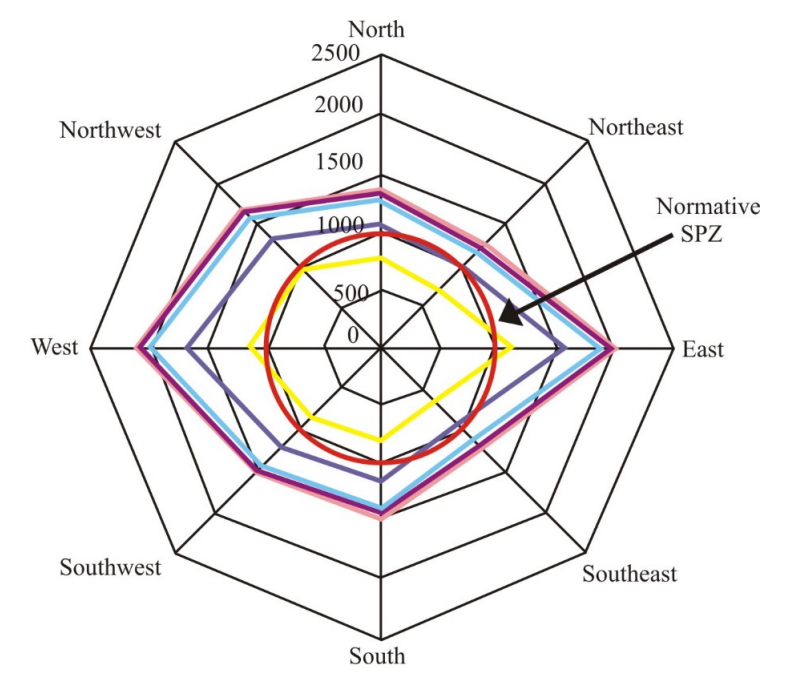

$-\mathrm{NO}_{2}$ at $a=1.6 \quad \mathrm{NO}$ at $a=1.6 \quad \mathrm{CO}$ at $a=1.0$

- $\mathrm{NO}_{2}$ at $a=1.3 \quad \mathrm{NO}$ at $a=1.3$

Fig. 6 Normative SPZ and adjusted dimensions for pollutants according to the windrose

\section{4. Determination of rational operation conditions} and parameters of the gas pumping unit

The studies conducted indicate that the amount of harmful emissions can be changedby controlling the GB operation conditions. According to the results obtained in the study of emissions of carbon monoxide and nitrogen oxides, it has been found advisable to regulate the GB operating conditions by changing the excess air coefficient. This will make it possible to reduce concentrations of nitric oxide $\mathrm{C}_{\mathrm{NO}}$ by $21 \%$, nitrous oxide $\mathrm{C}_{\mathrm{NO} 2}$ by $22 \%$ and carbon monoxide $\mathrm{C}_{\mathrm{CO}}$ by $37 \%$. It should be noted that reduction of concentrations of nitrogen and carbon oxides is inversely proportional to each other.

On the basis of the studiesconducted, reduction of concentration of nitrogen oxides in the GB emissions is achieved with an excess air coefficient within $\alpha=1$...1.1. Adjustment of the operating parameters should ensure lowering of the combustion chamber temperature. This was substantiated by the fact that as the temperature of the nitrogen molecule increases, air molecule is activated and becomes more oxidizing. That is, nitric oxides are formed in a greater quantity [18]. The coefficient of excess of primary air will have the most significant influence on temperature control [16].

In view of the significant excess of the MPC at values of $\alpha=1 \ldots 1.1$ (Table 4), it is advisable to develop special measures ensuring reduction of $\mathrm{CO}$ concentrations in the $\mathrm{GB}$ emissions.

In order to reduce influence of exhaust gases in operation of compressor stations on main gas pipelines, an installation and a method of purification from CO [19] have been proposed. Effectiveness of the device consistsin its service life (2,200 h for the AMQlamps). Reduction of dimensions consists in that ultraviolet lamps are directly located in the air stream from the compressor.

The proposed method for purifying from $\mathrm{CO}$ in exhaust gases of the gas turbine units consists in an additional supply of ionized air to the exhaust gases. An air compressor and an ionization chamber with UV lamps serve as themeans ofrealization of this method. In solving the set task,a fact was taken in account that the ionized $\mathrm{O}_{2}$ molecules in air are mixed with the emissions of gases contributing to turning $\mathrm{CO}$ gas into $\mathrm{CO}_{2}$.

\section{Discussion of results obtained in thestudy of emissions of gas pumping units}

As a result of calculations, it has been found that as the coefficient $\alpha$ increases, the near-earth concentrations of nitrogen oxides grow and those of carbon monoxide decrease. This is because of the fact that the excess air coefficient has the most significant effect on the temperature control in the combustion chamber where formation of nitrogen oxides is intensified with temperature growth.

Proceeding from the fact that it is difficult to reduce concentration of nitrogen oxides in the GB emissions by taking special measures in practice, only concentrations of nitrogen oxides should be taken into account when setting the combustion conditions. That is, from the point of view of environmental impact, gas in the GB cameras should be burnt at $\alpha=1 . .1 .1$. Establishment of this dependence makes it possible, without significant capital expenditures, to reduce harmful effect of individual emissions on environment in the GB operation. In this regard, it is appropriate to highlight some of the existing views on the priority areas of raising the level of environmental safety of the facility under study. For example, papers [20,21] place emphasis on the fact that one of the promising ways of reducing harm of exhaust gases at gas transportation units is introduction of a catalytic method of gas purification. The basis of this method was a heterogeneous catalytic reaction in which toxic nitrogen oxides in presence of a reducing agent react on the catalyst surface resulting in decomposition of harmful substances into non-toxic compounds. As it follows from the conclusions of work [22], the change in one and the same factor that affects the gas combustion can influence in different ways on formation of nitrogen and carbon oxides. Today, there are many ways of inhibiting nitrogen oxide formation reactions but it is difficult to realize them in practice because of certain specific features. In particular, such methods can significantly affect performance of the gas pumping unit. Work [22] proposed the technology of tubular combustion of gas as a way to reduce amount of nitrogen and carbon oxides. Such technology may in the long run become the basis for designing combustion chambers for new gas turbine engines and modernization of those currently used for pumping gas on main pipelines. However, all of the above technical solutions require significant investments and time to implement them. Study [14] presents a regression model that establishes relationship between $\mathrm{NO}_{\mathrm{x}}$ emissions,consumption of fuel gas and the excess air coefficient $\lambda$. To obtain more objective values, the study [16] analyzed measurements of the exhaust gas concentrations $\left(\mathrm{NO}_{\mathrm{x}}\right.$ oxides and carbon monoxide, $\mathrm{CO}$ ) depending on gas consumption $\mathrm{Q}$, the excess air coefficient, nominal power, and combustion temperature. As a result of multivariate correlation regression analysis, it was determined that the excess air coefficient has the greatest impact. A need to carry out a study of influence of this factor on the change of concentration of the GB exhaust gases for establishing rational operation conditions of the object under study. The multifactorial nature of influence of various GB parameters on concentration of emitted pollutants is complicated by the fact that units differ in their technical state, operation time, etc.

All this support feasibility of the proposed measures of implementation which may contribute to raising the level of environmental safety of the given object:

- optimize the GB operation parameters taking into account the excess air coefficientand its recommended values in the range of $\alpha=1 . .1 .1$; 
- introduce obligatory special measures and means for utilization of flue gases and make them safer [19];

- increaseheight of fume stacks emittinghazardous CS.

The proposed approaches may also be applied to other environmentally hazardous objects of the oil-and-gas industrial complex by adapting them to specific situations.

The results of this work determine the direction of further studies:

- development of methods for controlling concentration and automatic selection of optimal parameters that provide regulation and auto-blocking in excess of permissible pollution levels;

- creation of new methods and devices for reducing thevolumes of harmful exhaust gases and their toxicity.

Therefore, further studies are necessary to establish effects of other factors such as temperature of gas combustion, power of the GB, fuel gas consumption, shaft rotation speed which can have a significant impact on composition of emissions of the gaspumping units.

\section{Conclusions}

1. Dispersion zone for $\mathrm{NO}_{2}, \mathrm{NO}, \mathrm{CO}$ emissions at the excess air coefficient, $\alpha$, of $1.0 ; 1.1 ; 1.3 ; 1.6$ was simulated using the Eol-Plus, v. 5.23 software package. It was found that the pollutant concentrations exceeding the MPC required further adjustment of the sanitary protection zone size taking into account the local windrose.

2. Dimensions of the adjusted sanitary protection zone for various values of the excess air coefficient and according to the windrose have been establisheddue to the use of simulation. Dimensions of the adjusted sanitary protection zone take into considerationgrowth of the distance to which harmful emissions of nitrogen oxides and dioxides can reach with an increase in the excess air coefficient. The smallest emission spread occurred at coefficient $\alpha=1.00$ and the largest at $\alpha=1.60$.

3. The effect of the excess air coefficient, $\alpha$, on the nearearth concentrations of nitrogen oxides and carbon monoxide was established. With anincrease in coefficient $\alpha$, the near-earth concentration of nitrogen oxides increasedwhile carbon monoxide concentration decreased. It was found that concentrations of nitrogen oxides were minimal when burninggas in the GB chambers at $\alpha=1 \ldots 1.1$.

4. Recommendations and measures for prevention and reduction of influence of harmful substances on the environment of the gas transportation facilities have been developed. The use of a method of removingCO from exhaust gases in operation of compressor stations on main gas pipelines was proposed. It consists in an additional supply of ionized air in exhaust gases.

\section{References}

1. Shkitsa L., Yatsyshyn T. Computer-aided chart of ecological safety evaluation of atmospheric pollution by drilling fluid steams // Scientific bulletin of North University of Baja Mare. Series D. Mining Mineral Processing Non-ferrous Metallurgy Geology and Environmental Engineering. 2013. Vol. 27, Issue 1. P. 131-138.

2. Means of atmospheric air pollution reduction during drilling wells / Shkitsa L., Yatsyshyn T., Lyakh M., Sydorenko O. // IOP Conference Series: Materials Science and Engineering. 2016. Vol. 144. P. 012009. doi: 10.1088/1757-899x/144/1/012009

3. Shkitsa L. Ye., Yatsyshyn T. M., Sydorenko O. I. Metody pokrashchennia yakosti atmosfernoho povitria pid chas burinnia naftohazovykh sverdlovyn // Naftohazova haluz Ukrainy. 2017. Issue 5. P. 42-45.

4. Leshchenko I. Ch. Vprovadzhennia suchasnykh tekhnolohiy u hazotransportniy systemi Ukrainy dlia zmenshennia vykydiv shkidlyvykh rechovyn v atmosferu // Problemy zahalnoi enerhetyky. 2010. Issue 3 (23). P. 41-47.

5. Hovdiak R. M. Shliakhy pidvyshchennia enerhoekolohichnoi bezpeky ta efektyvnosti roboty mahistralnykh hazoprovodiv Ukrainy // Rozvidka ta rozrobka naftovykh i hazovykh rodovyshch. 2012. Issue 1 (42). URL: http://rrngr.nung.edu.ua/sites/ default/files/journals/042/12grmmgu.pdf

6. Directive 2008/50/EC of the European Parliament and of the Council of 21 May 2008 on ambient air quality and cleaner air for Europe // Official Journal of the European Union. 2008. L 152/1.

7. Southwestern Pennsylvania Marcellus Shale Short-Term Ambient Air Sampling Report. Pennsylvania Department of Environmental Protection, 2010. 52 p. URL: http://www.dep.state.pa.us/dep/deputate/airwaste/aq/aqm/docs/Marcellus_SW_11-01-10.pdf

8. Mykhailiuk Yu. D. Ekolohichnyi stan terytoriy kompresornykh stantsiy // Naukovyi visnyk NLTU Ukrainy. 2014. Issue 24.2. P. $119-125$.

9. Fighting global warming by greenhouse gas removal: destroying atmospheric nitrous oxide thanks to synergies between two breakthrough technologies / Ming T., de_Richter R., Shen S., Caillol S. // Environmental Science and Pollution Research. 2016. Vol. 23, Issue 7. P. 6119-6138. doi: 10.1007/s11356-016-6103-9

10. Samsonov R. O. Geological risk management by optimizing the compressor plant operation at the natural gas main pipelines // Oil and Gas Business. 2007. URL: http://www.ogbus.ru/eng/authors/SamsonovRO/SamsonovRO_2e.pdf

11. Wellenius G. A. Ambient Air Pollution and the Risk of Acute Ischemic Stroke // Archives of Internal Medicine. 2012. Vol. 172, Issue 3. P. 229. doi: 10.1001/archinternmed.2011.732

12. Primer on Short-Lived Climate Pollutants. Institute for Governance \& Sustainable Development, 2013. 147 p. URL: http:// www.igsd.org/documents/PrimeronShort-LivedClimatePollutantsNovemberElectronicversion.pdf

13. Kuznietsov S. I. Sposib ochyshchennia vidkhidnykh haziv kotelnykh vid oksydu vuhletsiu ta prystriy dlia yoho realizatsiy: Pat. 62855 UA. No. u2003098250; declareted: 04.09.2003; published: 15.12.2003, Bul. No. 12.

14. Yahoda P. A., Mykhailiv V. I., Kostiv V. V. Pobudova optymalnoi modeli funktsii mnozhynnoi rehresiyi dlia vyznachennia velychyn vykydiv NOx, shcho utvoriuiutsia v protsesi roboty HPA zalezhno vid vytraty palyvnoho hazu ta koefitsienta nadlyshku povitria // Rozvidka ta rozrobka naftovykh i hazovykh rodovyshch. 2007. Issue 2 (23). 
15. Varlamov G. B., Priymak E. A. Actual characteristics of compressor station equipment and optimization of loading main gas pipeline // Eastern-European Journal of Enterprise Technologies. 2013. Vol. 5, Issue 8 (65). P. 9-13. URL: http://journals.uran.ua/ eejet/article/view/18119/15867

16. Mandryk O. M., Tyrlych V. V., Mykhailiuk Yu. D. Bahatofaktornyi analiz kompleksnoho ekoloho tekhnichnoho obstezhennia hazoperekachuvalnoho ahrehatu na riznykh tekhnolohichnykh rezhymakh roboty // Naftohazova enerhetyka. 2015. Issue 2 (24). P. 44-52.

17. Metodika rascheta koncentraciy v atmosfernom vozduhe vrednyh veshchestv, soderzhashchihsya v vybrosah predpriyatiy, OND-86. Leningrad: Gidrpometeoizdat, 1987. 94 p.

18. Mykhailiuk Yu. D. Mekhanizm i faktory utvorennia oksydiv nitrohenu i karbonu pry zghoranni pryrodnikh haziv // Naukovi notatky. 2014. Issue 44. P. 179-183. URL: http://nbuv.gov.ua/UJRN/Nn_2014_44_30

19. Mykhailiuk Yu. D. Sposib ochystky vidkhidnykh haziv kompresornykh ustanovok vid SO: Pat. No. 102157 UA. No. u201413739; declareted: 22.12.2014; published: 26.10.2015, Bul. No. 20.

20. Levchenko O. V. Vykydy toksychnykh rechovyn v atmosferu z hazoturbinnykh ustanovok // Naftova i hazova promyslovist. 2000. Issue 1. P. 61-63.

21. Levchenko O. V. Ochyshchennia vykhlopnykh haziv vid oksydiv vuhletsiu // Naftova i hazova promyslovist. 2001. Issue 6. P. $62-66$.

22. Rezul'taty ispytaniy kamery sgoraniya GTD DG 80 s nizkoemissionnym gorelochnym ustroystvom na baze trubchatyh moduley / Lyubchik G. N., Romanov V. V., Vancovskiy V. G., Vilkul V. V. // Eastern-European Journal of Enterprise Technologies. 2009. Vol. 4, Issue 6 (40). P. 13-18. URL: http://journals.uran.ua/eejet/article/view/22016/19523 